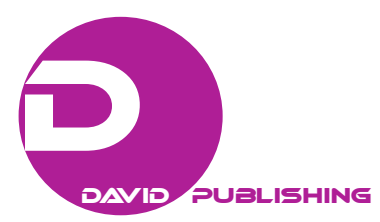

\title{
Strategic Management of Independent Film Production
}

\section{Companies}

\author{
Ieva Vitkauskaite \\ Vilnius University, Vilnius, Lithuania
}

\begin{abstract}
This article introduces the analysis of strategic management of film production companies. The first part presents processes and models of strategic management and introduces a new and unified model of strategic management. It is noteworthy that the film/film industry value chain helps to understand the notion that the links between separate stages have an impact on the company's competitive advantage and reveal how the main product in the film industry, the feature film, is developed. Therefore, the following part analyses models and composition of film industry value models. The final part of this article analyses the main features of a film production company and the sources of funding thereof. The strategic model of independent film production companies is based on the characteristics of strategic management and the value chain models of independent film projects.
\end{abstract}

Keywords: strategy, strategic management, film production company, strategic management of film company, strategic management model

\section{Introduction}

The analysis of independent film production, which in principle does not belong to the Hollywood system, reveals that it is fragmented, poorly structured and, therefore, a highly complicated business (Finney, 2008, p. 107). The main problem is related to its incapability of sustainable development. Even though film sector receives state support through various instruments (e.g. reduced tax rates, etc.) (Strazdas, Černevičiūtè, \& Jančoras, 2014, pp. 28-29), it is not enough for a successful development of a film company.

It is noteworthy that the development of the company depends on its strategic management which, according to Domazet, Stošic, and Zubov, is the fourth stage of the planning system (2011, p. 80), and which is based on the strategy (Melnikas \& Smaliukiene, 2007, p. 8). In other words, strategic management is a constantly repeated process of organisation management which connects the adoption, planning, and execution of the current solution and the long-term strategy of organisation (Ambler, 2016).

A properly crafted and implemented strategy (which differs considerably from that of the competitors) can help to ensure the development of the company. It is noteworthy that the budget of film projects/feature films can be as high as several million euros. Therefore, the company must form its model of strategic management in a way that it would allow structuring the activity and maintaining the integrity.

The aim of this article is to analyse the process of strategic management of independent film companies. In order to achieve this aim, systematic scientific analysis of literature has been conducted.

Ieva Vitkauskaite, Ph.D. student, Kaunas Faculty of Vilnius University, Kaunas, Lithuania.

Correspondence concerning this article should be addressed to Ieva Vitkauskaitė, 8 Muitinès str., LT-44280 Kaunas, Lithuania. 


\section{Processes of Strategic Management}

Scientific literature deals with various processes of strategic management. In his analysis of strategic management, O'Shannassy (2003, p. 59) suggests a process of strategic management that consists of two main parts: strategic thinking and strategic planning. The process between these two elements is continuous.

According to Fishel $(2008$, p. 23), strategic thinking is a process that reveals the prospects of management of future activities by taking into account all types of environment as contributing factors. It is an ability to connect the present with future prospects. It is claimed that strategic process starts from strategic thinking, with the latter being present throughout the entire process of management. This is confirmed by Figure 1 which reveals the composition of the map of strategic thinking.

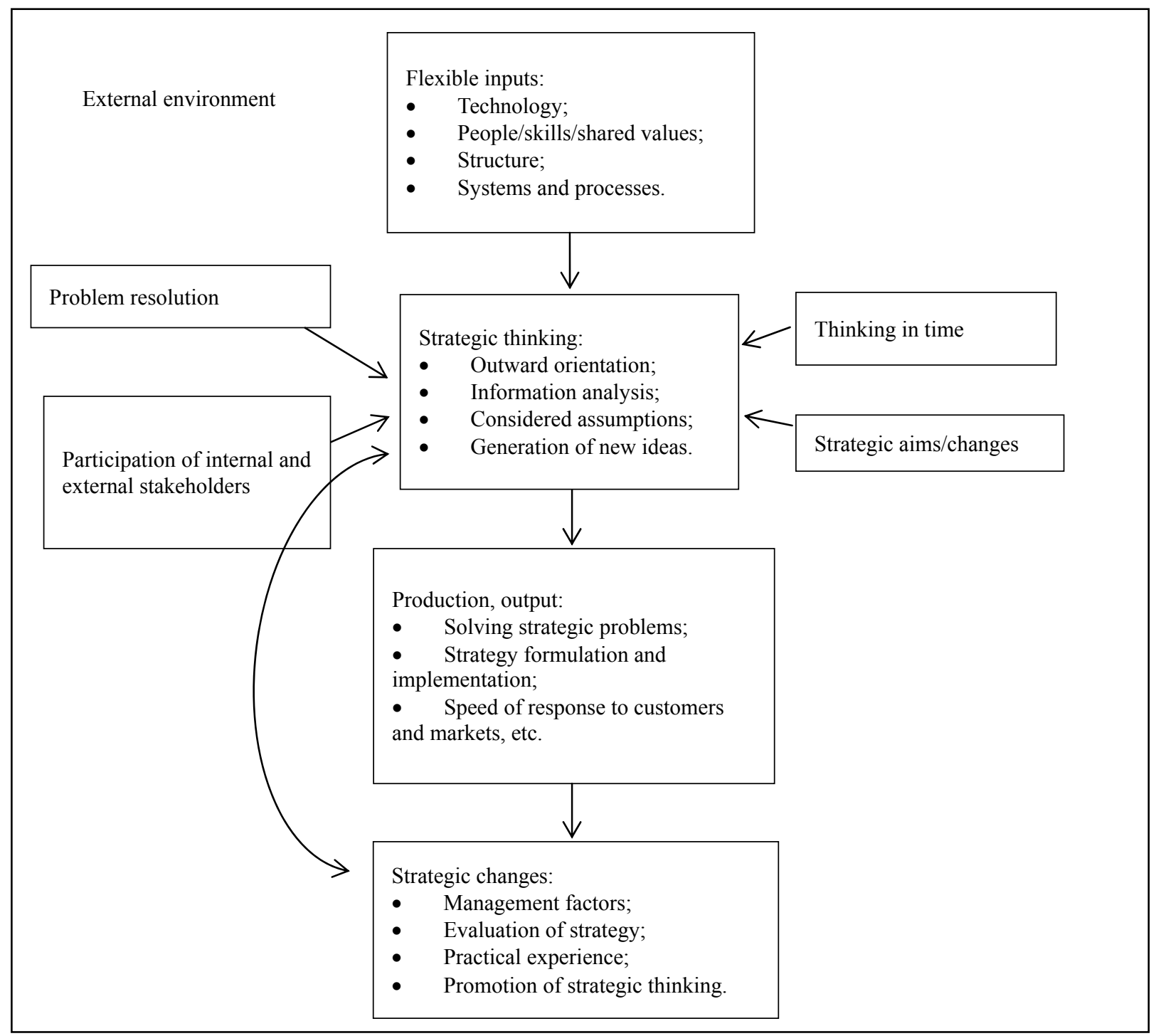

Figure 1. Map of strategic thinking. Source: Based on O’Shannassy (2003, p. 58); Swayne, Duncan, and Ginter (2008, p. 12).

Figure 1 shows that strategic thinking consists of information analysis, outward orientation, assumptions and generation of new ideas. Additionally, it must include problem resolution, thinking in time, strategic aims/intentions, contribution (people, skills, etc.), and participation of stakeholders, in case of a larger company. 
According to O'Shannassy and as seen in this figure, the process of strategic management includes the strategic planning. Strategic thinking is followed by production/output, and strategic changes that feature the following parts of strategic planning: case analysis, strategy formulation, and implementation planning (Swayne, Duncan, \& Ginter, 2008, p. 12). Strategic thinking influences the entire process of strategic management, because it helps to adopt solutions, implement aims, etc.

Not only does the process of strategic management consist of strategic thinking, it includes strategic planning as well; the said planning includes the determination of organisation's plans which allows achieving the mission of organisation (Gates, 2010, p. 3). Strategic planning can include certain elements illustrated by Figures 2 and 3.

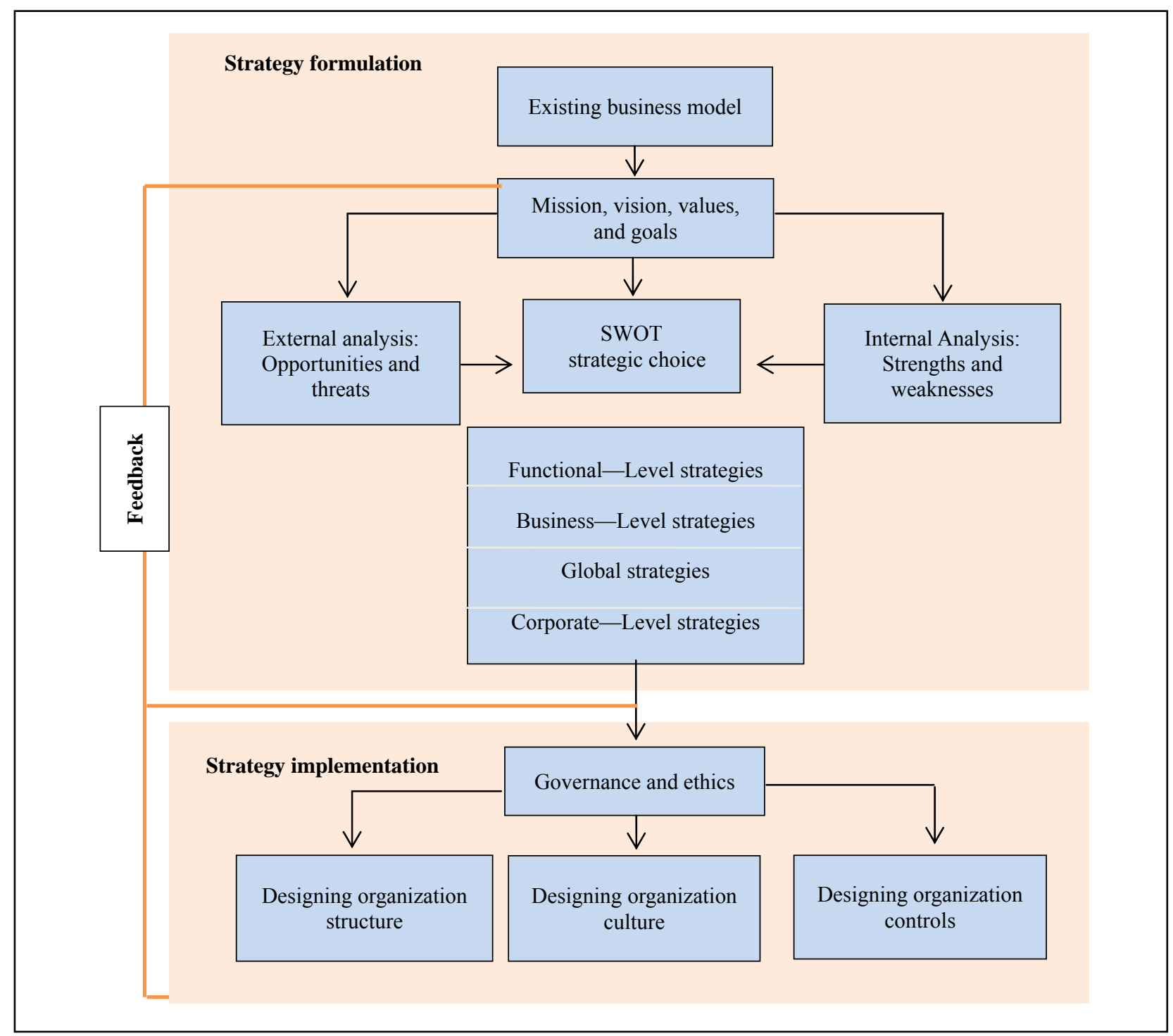

Figure 2. The main components of the strategic planning process. Source: Hill, Jones, and Schilling (2015, p. 13).

According to the data provided in Figure 2, the formulation of strategy consists of an existing business model, mission, vision, value, aims, SWOT, and various levels of strategies and feedback. There are four levels of strategies: 
(1) Corporate strategy. The top-level strategy that indicates what the company should be like. It establishes the structure of the company, the formula of its future and actions that enable competition (Ritson, 2011, p. 19);

(2) Global strategy defines production and provision of services on the global level (Peng, 2014, p. 19);

(3) Business and competition strategy; orientation towards the increase of the competitive advantage (Valentinavičius, 2009, p. 132) in order for business to survive and grow in the future (E. Papulova \& Z. Papulova, 2006, p. 4);

(4) Operational or functional strategy is the lowest level of strategies (Arimavičiūtè, 2007, p. 81) which analyses how different functions of business (marketing, production, finances, etc.) help corporate and business strategies (Ritson, 2011, p. 19). All functional activities must be coordinated and supplement each other, because each strategy is an integral part of a strategy listed above it.

Strategy formulation is followed by the next stage-implementation. It consists of management and ethics, organisation control, structure and cultural design. Feedback exists in all stages and elements.

Gates distinguishes two main blocks of strategic planning, What and How, depicted in Figure 3.

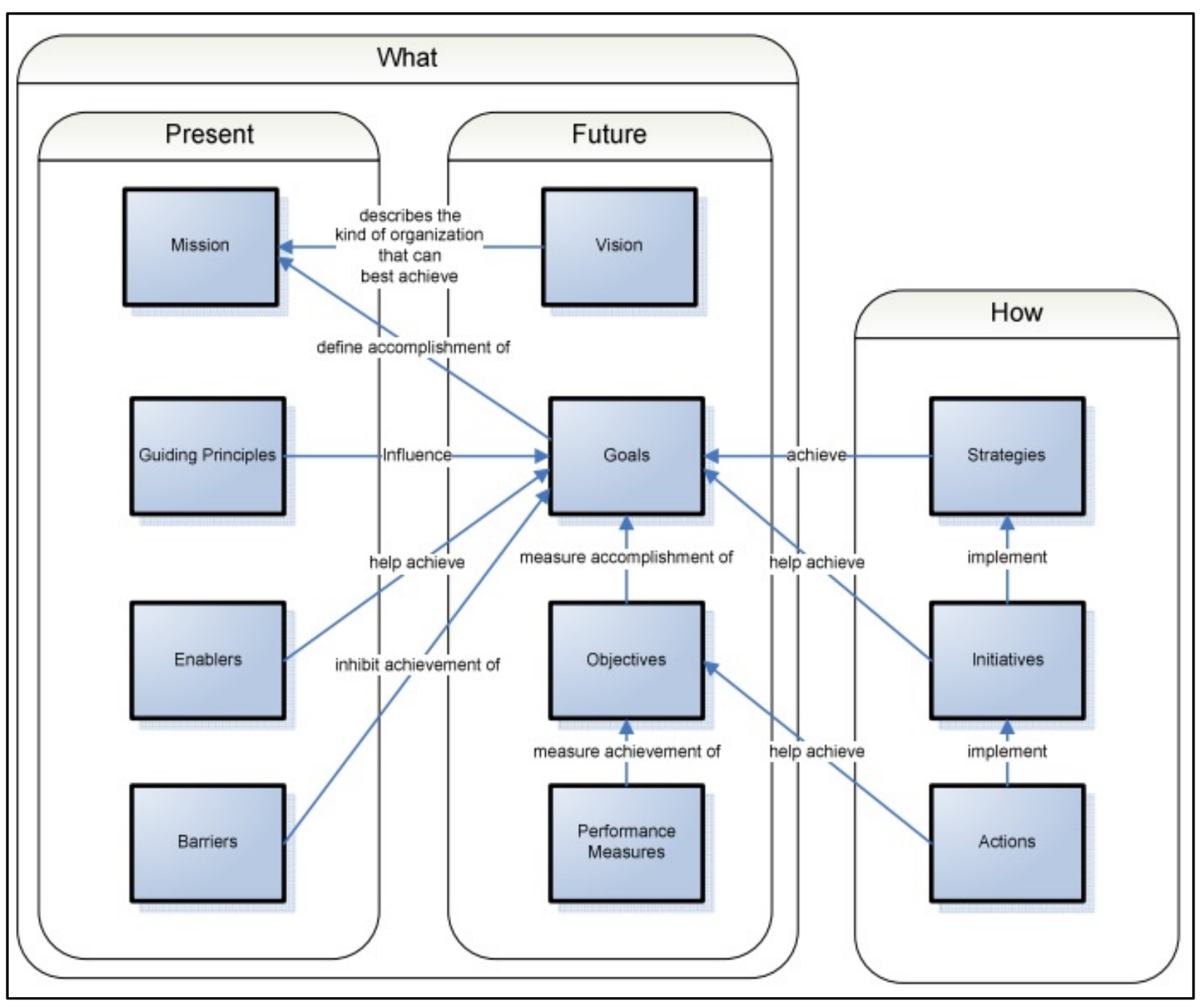

Figure 3. Typical elements of strategic planning. Source: Gates (2010, p. 4). 
The What block consists of two subsections: the present and the future. It is noteworthy that when creating the strategy for an organisation, the first thing to do is to find out where organisation is at the given time (present) and what it wants (future); only then it is possible to start considering how organisation will achieve its aims. Usually organisations focus only on How, without knowing what they want and where they are; consequently, this might result in a failure.

Salas and Huxley (2014, p. 110) note that once the strategies are created and developed, another important step is communication of the said strategies and actions related to them in the entire organisation. Usually managers provide their employees with limited descriptions only, indicating what they should do and why the tasks provided are important. This can also result in failure. Communication between the employees must be developed in order for all actions, initiatives, and strategies in the organisation to be implemented successfully.

Comparing these two breakdowns of strategic planning (Figures 2 and 3), it can be said that the said elements are similar yet named differently. The key difference between these breakdowns is the fact that Gates emphasises the position of organisation at the moment and what kind of future it wants.

If we add the elements of strategic planning and strategic thinking into the composition of the aforementioned strategic business model by Hill, Jones, and Schilling (2015), we can achieve a more detailed breakdown of the strategic business process. However, this would not be the only breakdown of strategic management process. Frynas and Mellahi (2011, p. 6) suggest a breakdown of strategic management process that consists of three elements of the following order: strategic analysis, strategic development and, finally, implementation of strategy. The authors do not identify strategic management as a cyclical one. In this case, everything ends with implementation of the strategy. One can agree with the said authors, except the fact that the definitions of strategic management refer to it as a process that repeats itself constantly. However, this process should be actually depicted as ceaseless. If we compare the approach of these authors to process stages suggested by O'Shannassy (2003), Swayne, Duncan, and Ginter (2008), one can say that they provide a broader approach for strategic management, because their process includes strategic thinking as well. One can also wonder why Frynas and Mellahi do not include the stage of strategy formulation. Maybe it is included into the step of strategy implementation; however, it is not clear based on strategic management stages named by the authors.

Strategy is the key for strategic management. It is included into every definition and model of strategic management process and reflected in Morden's scheme of strategic management process (Figure 4).

This process (Figure 4) also distinguishes strategic analysis as well as formulation and implementation of strategy. There is an additional stage of strategy choice which follows strategy formulation. It means that there are several strategies formulated and several strategic solutions adopted; only then, the most suitable one is selected. As visible from the picture, it is a continuous process. Alongside the strategy process, feedback and training take place as well. Training enables the improvement of strategic solutions and encourages strategic thinking. It can be said that strategic planning and thinking elements are listed in the smaller circle. All elements form the entirety of solution adoption process.

The analysis of the strategic management breakdown is continued by the introduction of another breakdown (Figure 5) which is more detailed than the previous one.

Comparison of this Model of Strategic Management (Figure 5) to Strategic Planning Elements by Gates (Figure 3) reveals that strategic planning consists of the following main elements: the present (where 
organisation is now), future (where the organisation wants to be), and How. It is noteworthy that assessment is also distinguished, because it is important for organisation to conduct analysis of actions in order to figure out whether it has achieved its goals. The figure shows that the section of Employee Performance is distinguished and featured as including employee feedback monitoring, increase in mutual communication, etc. There is also the management performance which includes leadership competences, continuous development of management team, etc. It shows that successful strategic management requires a strong team and good communication.

Figure 5 shows that after the overview and analysis of actions, the next stage is that of comparative analysis. Usually this analysis is conducted for the most efficient organisations and market leaders. This analysis is oriented at any improvement of business process using the best practice, rather than a simple measuring of results. The study of best practices enables organisations to gain strategic and financial advantage. Comparative analysis is mostly focused on identification, analysis, and adoption of best practices as well as achieving the outcomes (Kelessidis, 2000, p. 2). Therefore, the process of strategic management consists not only of the internal analysis, and analysis of the actions carried out, but also through the study of competitors in order to outperform them. The breakdown depicted by Morden (Figure 4) includes training that allows the improvement of strategic solutions. This can be compared to the external comparative analysis, as it involves learning from the market leaders and thus encouraging the strategic thinking.

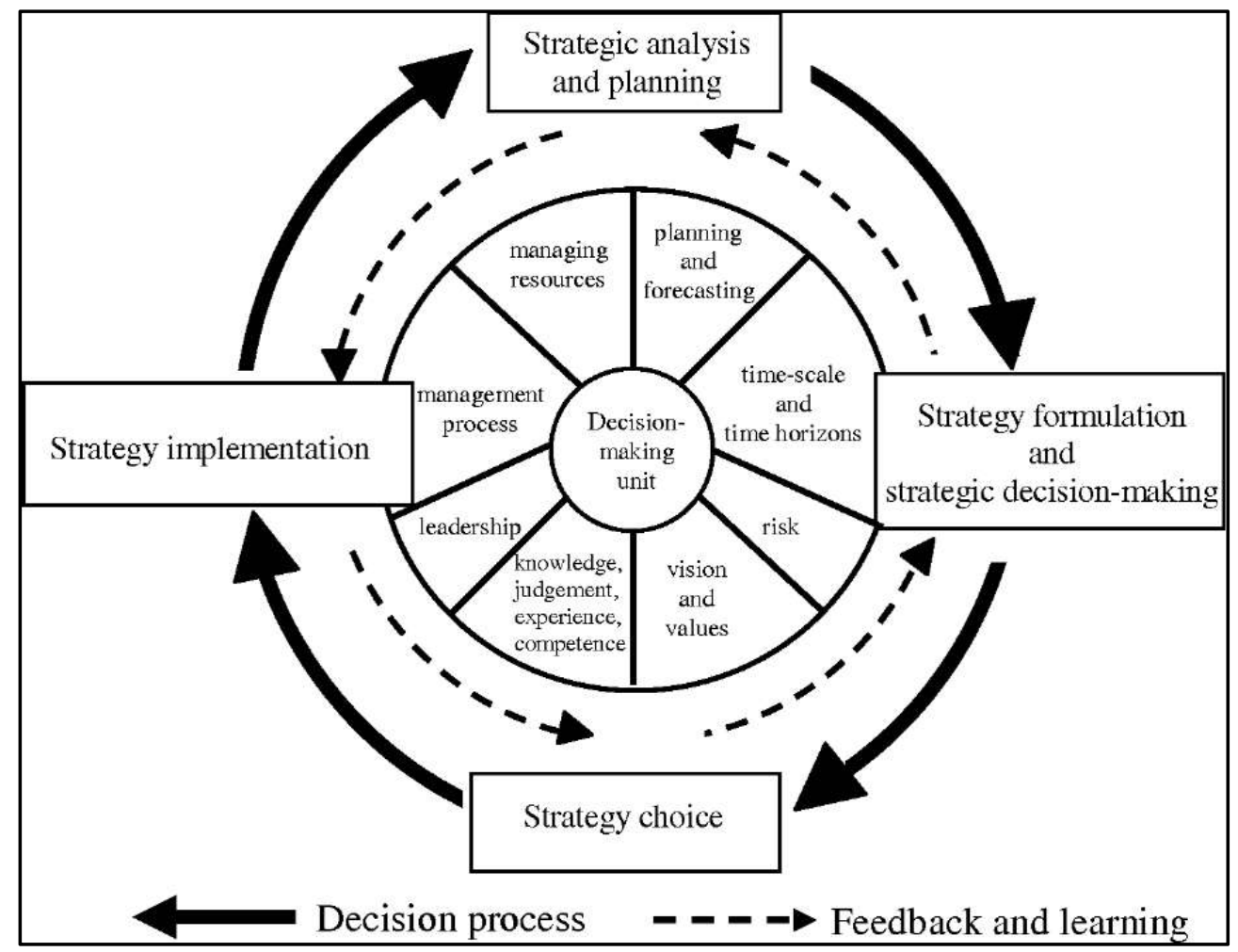

Figure 4. Strategic management process. Source: Morden (2007, p. 19). 


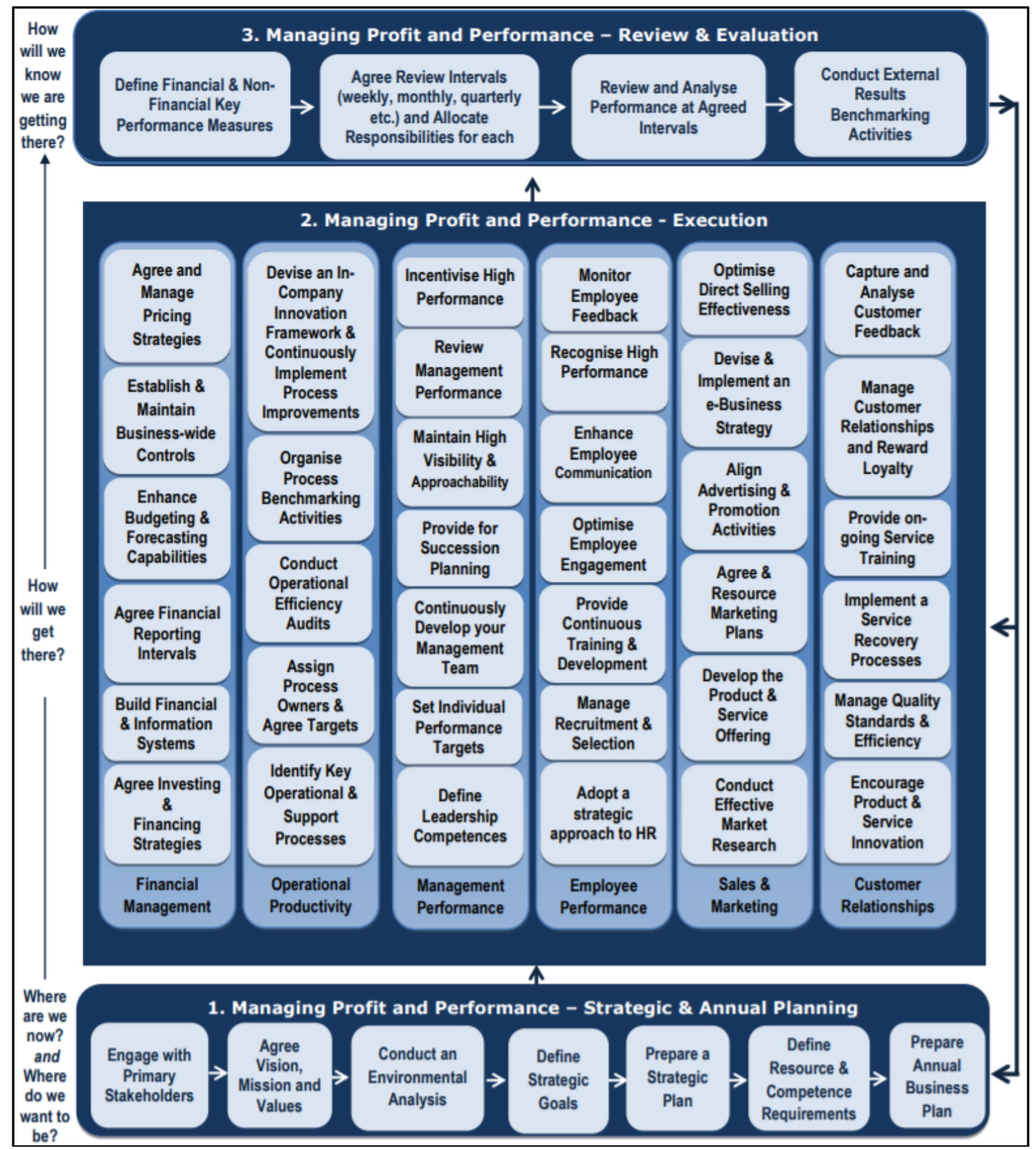

Figure 5. Model of strategic management. Source: Failte Ireland (2013, p. 5).

After the analysis of strategic management processes established herein, a summarising model of strategic management processes is provided in Figure 6. 


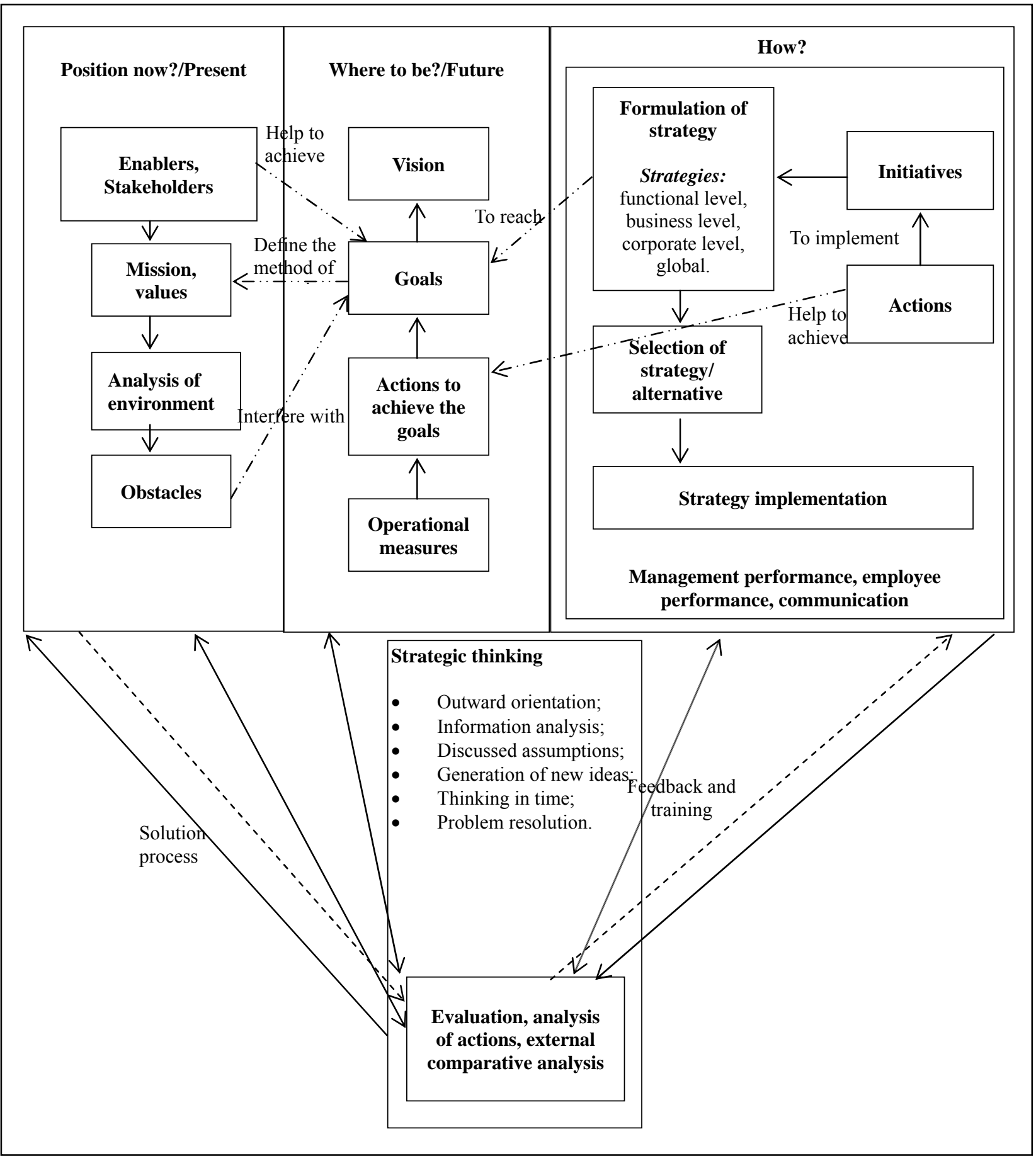

Figure 6. Process of strategic management. Source: Compiled by the author.

This process of strategic management (Figure 6) consists of evaluation of three blocks of strategic thinking: Present, Future and How. It is noteworthy that the assessment and control is executed in each block. The process of strategic thinking is continuous and repetitive. However, it starts from the point at which organisation is at the moment: stakeholders, mission, values, environment analysis, and assessment of the obstacles that interfere with the achievement of goals defined and which determine the future of organisation. 
The achievement of goals results in implementation of the vision. However, in order to achieve them, one must formulate the strategy and implement it as well. At this stage, communication with employees also plays an important role, because it enables easier implementation of the strategy and reduces the resistance, if any. Therefore, organisation creates a plan about how to achieve the goals that would bring it to the point in the future where it sees itself to be.

In conclusion, there are various processes of strategic management. The following parts of the process are distinguished as the main ones: strategic thinking, mission, vision, goals, formulation of strategy (strategies: functional, business, corporate level, and global), selection of strategy, implementation of strategy, strategic analysis, external comparative analysis. The actions are coordinated and evaluated during the entire process; training is also a part of the said process. In order to implement strategy in an organisation, the quality of communication must be high. It is noteworthy that when implementing a strategy, the organisation must realise where it is at the moment, what it wants and only then can it plan how to achieve it. Strategic management is a continuous and repetitive process for the management of the entire organisation.

\section{The Model of Independent Film Industry Value Chain}

The market of film industry is ever-changing, unpredictable, and involving continuous creation of new strategies. Strazdas, Černevičiūte, and Jančoras (2014, p. 35) claim that in the market of cultural goods, strategies are based on intuition, emotional knowledge rather than standard market studies. One can agree with the opinion of authors, except for their claim that studies are unnecessary. Studies in the cultural field and film industry contribute to a better understanding of the audience and competitors; therefore, it facilitates the prediction of the success of a film, company activity, audience reach, etc. The creation of the most important product of a film production company, the (feature) film, requires great financial resources; therefore, it is very risky to rely on the intuition only.

One can say that consumer taste for films is hard to predict (Lorenzen, 2008, p. 3); however, the knowledge of one's audience and its preferences might help to attract them by, for example, casting their favourite actor, introduction of innovations in the distribution process, educational activities, etc. When creating a strategy which in its turn forms the basis for the strategic thinking, one must first comprehend the film industry value chain. According to Mickevičienè (2011, p. 8), the value chain helps explain the notion that elements connecting different links have a decisive influence on competitive advantage. It is like an environmental analysis that allows identifying chains in which organisation is vulnerable or holding the advantage.

Film industry distinguishes various models of value chain. Finney provides the value chain of independent film sector depicted in Figure 7.

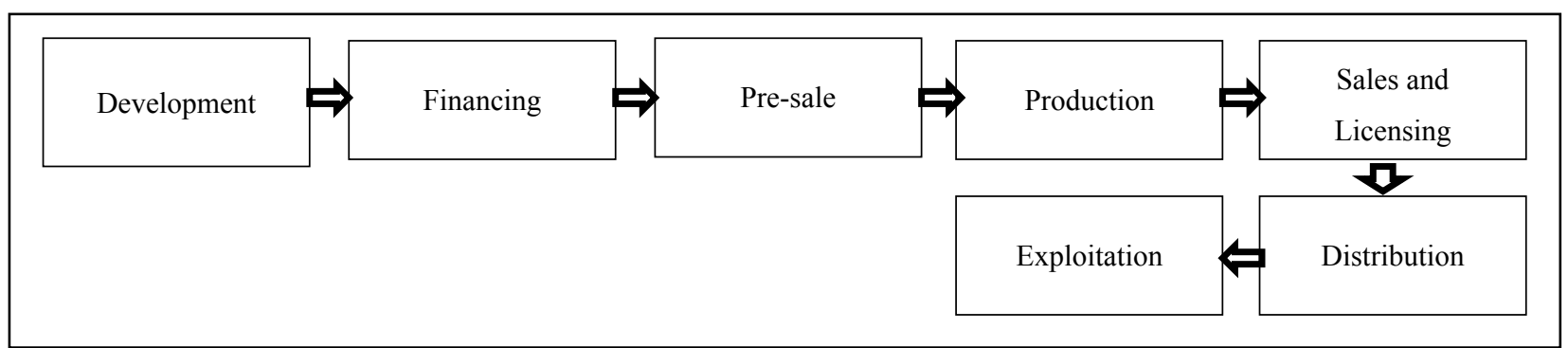

Figure 7. The existing film value chain model with seven stages. Source: Finney (2014, p. 5). 
This chain (Figure 7) introduces the main parts of film industry: production, distribution, and screening. However, the author distinguishes the main parts of film industry without putting the emphasis on the main elements of its constituents. It starts from the development and is followed by financing, mostly involving the producers and writers. It is noteworthy that there is no guarantee that the work of producers and writers shall create value. "The extended Film Value Chain leaves the producer far away from the consumer, and is often uninformed about market demands and user behaviour" (Finney \& Triana, 2015, p. 5). Relationship between European film producers, sales, and distributors is essentially unstable (Finney, 2014, p. 5) and it might endanger the film project additionally.

Figure 7 reveals that there are three stages before film production (the beginning of shooting): development, funding, and pre-sales. Usually film projects do not even reach the production stage, if one of the said preceding stages has not been completed successfully. Production is followed by sales, distribution, and exploitation. Exploitation stage can be treated as a screening stage. However, these stages are not described in detail.

Finney suggests another value chain model depicted in Figure 8.

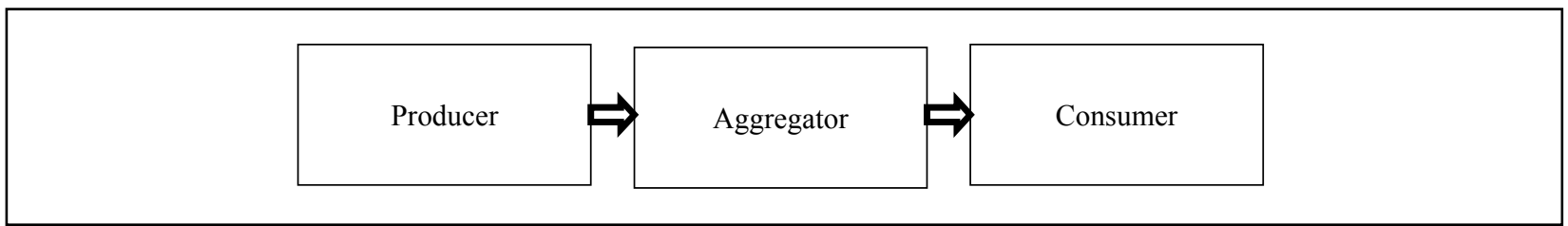

Figure 8. The new value system. Source: Finney (2014, p. 6).

The New Value System (Figure 8) emphasises the main participants of film industry: producers, aggregators, and consumers. In this case, the role of aggregators is filled by the likes of Google, Amazon, Apple, etc. (Finney, 2014, p. 6) wedged between the producer and consumer, thus reaching the widest audience possible. Film industry is closely related to technologies; however, to achieve accuracy, one value chain should include all of its components. For example, in film industry, an important role is played by stars whose presence in the film might attract the viewers. It might also serve as a part of marketing which Küng distinguishes in her film industry value chain as well (Figure 9). It should be noted that marketing ought to be started as early as in the production stage, while the shooting still takes place. Marketing plan includes advertising, production of trailers, publicity (articles about the film, media, interviews with film stars, etc.) (Küng, 2008, p. 72). However, there is a difference to Finney's value chain (Figure 7). It is noteworthy that Küng mentions marketing in the distribution stage (where it usually takes place); however, it is also included in the screening and licensing stage. Marketing starts from the production stage and follows throughout the next stages thus taking an important position in film industry.

The value chain in Figure 9 provides more insight on what it concludes a certain stage and its main features. For example, the first stage consists of the screen play, contracting talents, and securing financing. Production stage consists of planning, filming, and editing \& post-production, thus providing additional details about the composition of the value chain in film industry. However, not only should the chain include screening in cinema theatres and home videos, but it should also distinguish the digital (through IT) film distribution and screening as suggested by Finney in his value chain (Figure 8). Nilsen and Smistad (2012, pp. 5-8) notice that the Internet, IT and other similar factors tend to edit the value chain. All of it enables the development of 
innovations in the stages of film production, licencing, distribution, and screening. Figure 10 reveals the flow of digital content in film industry.

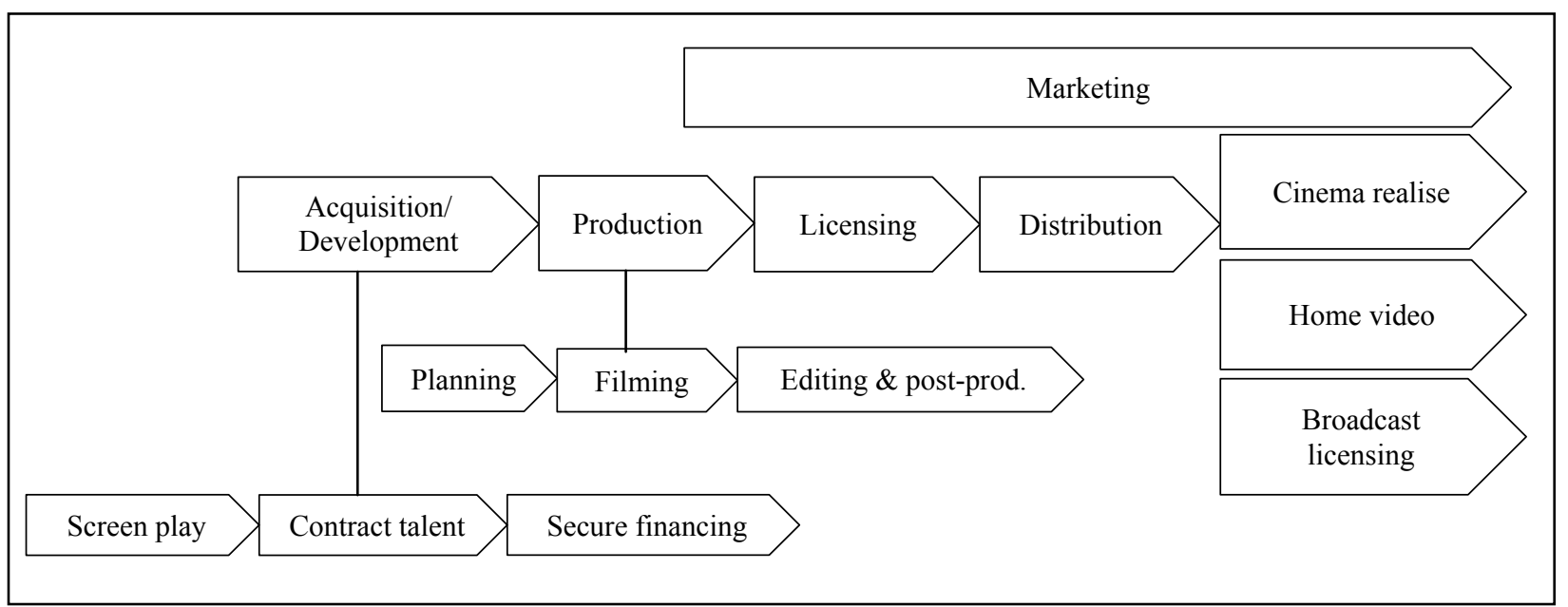

Figure 9. Value chain-The film industry. Source: Küng (2008, p. 71).

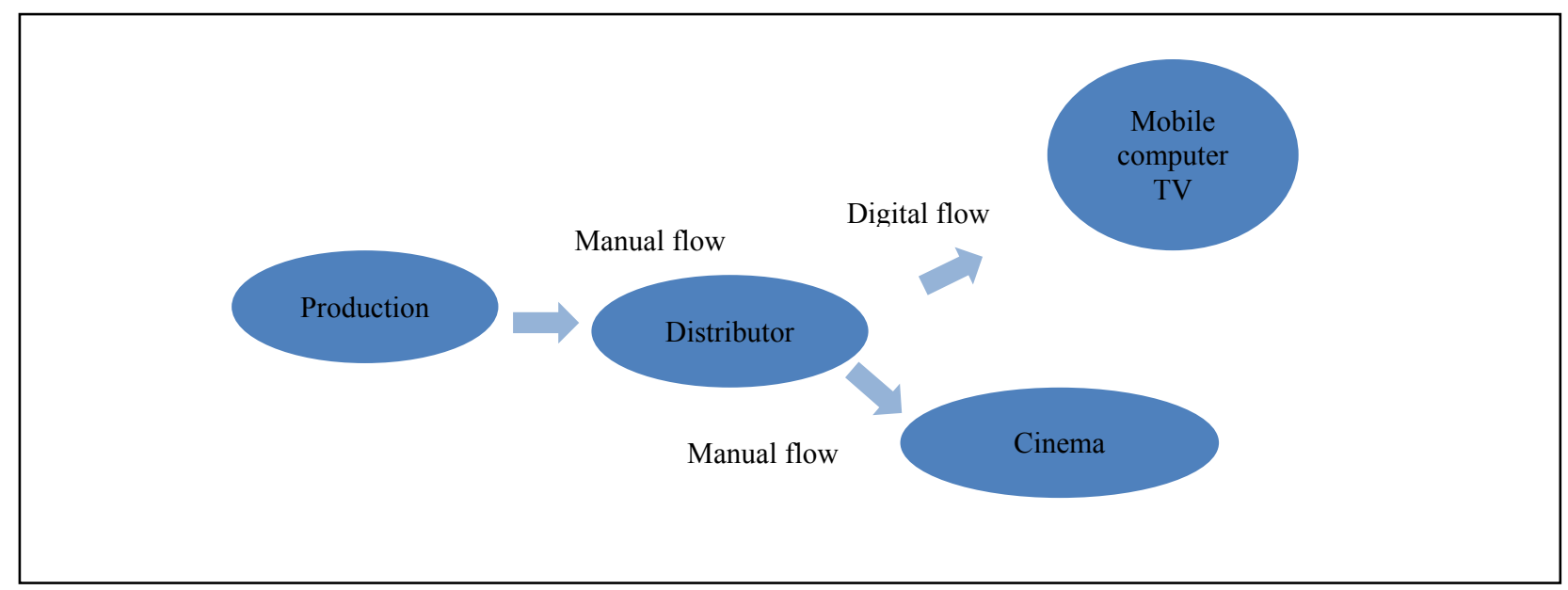

Figure 10. Digital cinema-Content flow. Source: Nilsen and Smistad (2012, p. 6).

Figure 10 shows a distinction between a manual and digital distribution. IT, television and other media-related elements are treated as a part of the flow of the digital content. Cinema theatres use external drives for screenings; therefore, they are assigned to the category of manual flow, because external drives and cinefilms must be transferred manually. In case of the digital flow, the film reaches the consumer at any place without the use of external drives or cinefilms required to watch them. The producer can, of course, distribute film through the digital flow at once and thus transfer it to distributors or film goers and consumers. However, this is more often the case with short videos, short-length films, trailers, etc. There are various channels for distribution besides cinema theatres, including the Internet, cable television, etc.

Wirtz's value chain is similar to chain values compiled by other authors; it includes procurement/pre-production, film production/post-production, trade of rights/movie rental and exploitation. There is no stage of distribution, as it is treated as a part of the trade of rights/film rental stage (Wirtz, 2011, p. 216). Daidj (2015, p. 254) claims that marketing must be developed in all stages, starting from the development. 
However, it is risky to start marketing as early as in the budget planning stage while still looking for financing sources. Independent film companies cannot always be guaranteed that a film they plan will receive funding. It is better to start marketing, when funding is received and film production has been started.

Value chain models are not entirely detailed, per se; each model has its drawbacks and requires certain improvements. However, the analysis of value chain models suggested by other authors (Aarhus, 2011; Bloore, 2009) reveals that similar parts are mentioned in them as well: development, financing, and pre-sales, production/shoot and post, international sales and licensing, international distribution, exhibition and exploitation, and consumption. Legal advisors, accountants, and consultants work in all stages of the work. Value offer (product/service proposition) is located between the stages of exhibition and consumption. Therefore, the value offered is the film at the screening stage. There are various market segments distinguished: film critics, the entire society, persons that have great influence on film industry, etc. (Aarhus, 2011; Bloore, 2009).

It is noteworthy that the most difficult stage is that of financing and pre-sales. In terms of investment, a feature film is the most expensive form of art (besides architecture). Each investor has its own needs and creative attitude which might affect the film. In this stage, independent films usually draw in a wide range of business collaborations, consultants, and investors (Bloore, 2009, p. 9). In the first stage, the risks related to the investment are considerably higher than when moving towards the final stage. Moving closer to the consumer, investment risk potentially decreases.

It can be said that the greatest power in the production stage belongs to the film director, when shooting, editing and other related activities take place. When the film is completed, it is sent to distributors. Usually a certain per cent from distribution earnings returns back to investors. In the consumption stage, the consumer sets the film value and its long-term reputation (Edictive, 2013). It is noteworthy that Bloore distinguishes the "Long Tail" stage, which starts at the screening stage and ends at the stages of international sales and distribution. It is a value chain, in which distributor or producer relaunches the film and its merchandise (Edictive, 2013).

Each stage of the value chain takes a certain period of time. For example, the development stage might take two to eight years, financing and pre-sales might take $1 / 2$ year to two years, production might last $1 / 2$ year, etc. However, it does not mean that the same intervals are applied in all cases. In each film project, the intervals are different and depend on the project itself (Bloore, 2009, p. 15). However, in film industry, the film itself is not the only product. Franchising is an increasing form of cooperation among companies which allows the exploitation of secondary products in film industry (e.g. video games, toys related to films).

In conclusion, there is a variety of value chain models. The value chain of independent film project includes the development, financing, pre-sales, production, shooting, post-production, international sales, licencing, international distribution, exhibition, exploitation and consumption. Legal advisors, accountants, and consultants work in all stages of the work. It is noteworthy that marketing takes an important role in the film industry. It starts at the production stage. Consumers who participate in the final stage contribute as determiners of film's reputation.

\section{The Model of Strategic Process Management in Independent Film Production Companies}

Each feature film is a project (Finney, 2008, p. 107), because each film production contains project characteristics (e.g. limited time, access to a strict or limited budget, etc.). The main manager of the project 
(from the beginning until the end) is film producer who takes a very important role in the process. Producers participate in the main stages: development, production, and distribution (Finney, 2008, p. 109).

The organisational structure of film production might vary depending on the size of the film, company, producer's management style, etc. Hope (2016) notes that the varying treatment of organisation structure reveals that the process is approached differently as well. This means that film production process differs too. There is no unified model for companies to base their work on.

Maurer has compiled the map of film development process which is introduced in Figure 11 below.

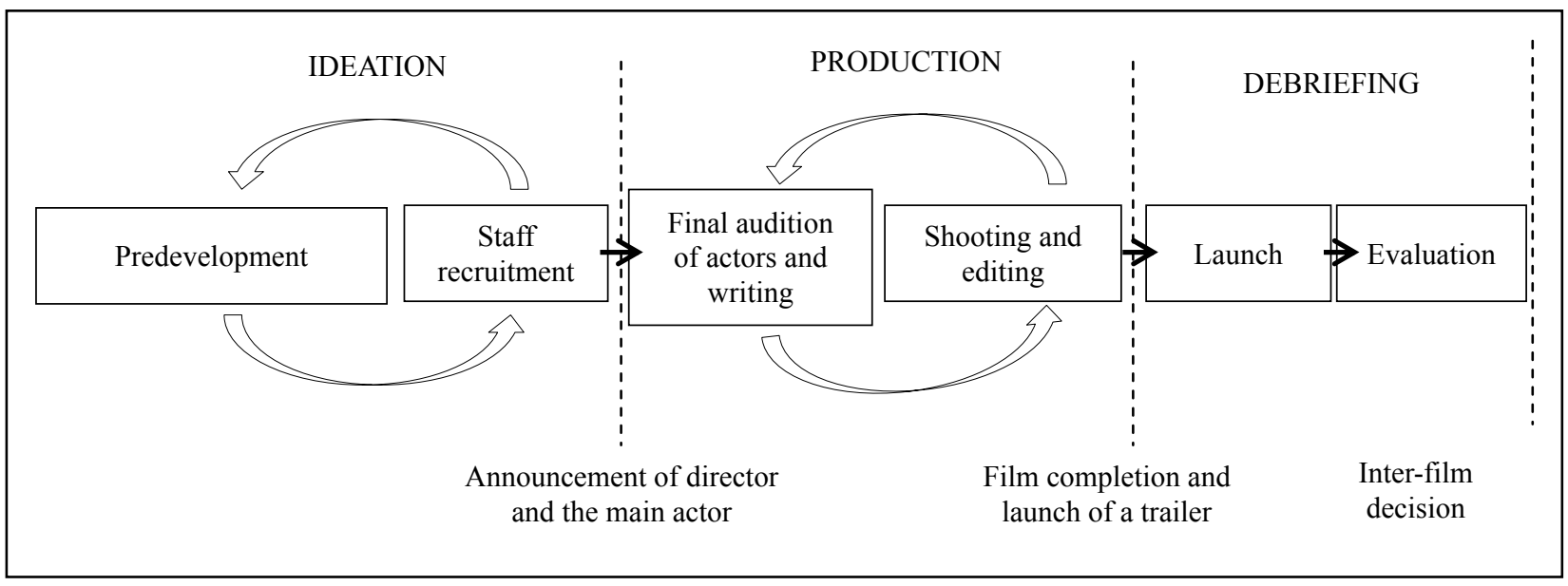

Figure 11. Map of the film development process. Source: Maurer (2008, p. 67).

Figure 11 shows that the process is cyclical until the stage of completion and launch of the film. The entire map consists of three main parts: ideation, production, and debriefing. If comparing to value chains analysed in the previous chapter, it could be treated as one more film industry value chain; however, this map puts more focus on the production of the film itself, emphasising the links between the most important stages of film creation; for example, between the final audition of actors and shooting, the course of action is always a cyclical one. Moreover, this process reveals the most important film production stages.

In order to start film production, it is necessary to secure funding. Funding of independent film production companies is more difficult than in the case of Hollywood studies. Film producer looks for various sources of financing; the following sources are possible:

- Private investors;

- Banks (loans, etc.);

- "Angel" investors (Finney \& Triana, 2015, p. 84);

- Risk capital companies;

- State subsidies;

- Various financing funds (local, regional, international);

- Income from product placements;

- Hedge funds (Campisi, 2012, p. 20);

- In case of an international coproduction, it is possible to receive financing from foreign funds. It might include not only the accumulation of the necessary budget, but creative elements as well, other resources of the country, taking advantage of tax deductions and similar incentives (Morawetz, 2007, p. 9);

- Fiscal incentives (tax incentives in the country of operation); 
- Funds from pre-sales;

- Crowdfunding;

- Television broadcasters;

- Funds of the company itself;

- A contract with major film studios ${ }^{1}$.

In the European film industry, financing usually consists of the combination of public and private sources (Jäckel, 2003, p. 43). It is noteworthy that independent film producers face the paradox: they cannot select talents and develop the production screen plays without financing; however, they cannot also receive financing without talents and a flawless screenplay (LCA, 2006, p. 5). This paradox is highly prevalent in recently established film production companies, in which film producers do not take a solid position in the film market. In such case, it is advised to start from short films as they require less funding and help to establish connections in film industry.

According to Goettler and Leslie (2004), such authors like Desai, Loeb, and Veblen claim that financing strategy is the main variable that shapes the industry. For example, co-financing, when several companies share film production costs and revenue is used even by major film studios. This practice might be illustrated by a highly successful high budget film Titanic which was produced by two competing studios, Fox and Paramount. Co-financing helps to manage the risk and studios can invest into high budget films.

Strategic management is a mechanism best revealed in the analysis of film companies. One of the largest independent film companies in the UK is Vertigo Films (currently, with the team of 20 employees). Within three years, this company has increased its revenue by almost 600 per cent. One of the strategies of the company is to find a talented yet still unknown director and help him to create a good low budget film. Another part of company strategy is to become involved into every stage of film development, i.e. production, post-production and special effect, sales and distribution. The company never looks for outside funding (Yakowicz, 2016).

It is noteworthy that it is not enough for film production companies to take into consideration the individual qualities of film production; the management of the entire company must also be taken into consideration. In this case, one has to formulate the overall strategy of the company the shaping of which starts from the overall company business model. There might be various business models to choose from. For example, there is a product-oriented model, when decision making is focused on the product, by aiming at the best quality of the product, expecting that the market will evaluate the quality of the product positively (Guild \& Joyce, 2006, p. 266). Each company forms an individual business model which is the best for their needs.

However, one should not forget that film production companies are highly influenced by micro- and macro-environment. Micro-environment has a direct influence, while macro-environment has an indirect one. Micro-environment includes such factors like funding institutions, funds, clients, media, sponsors, governmental organisations, all-level policymakers, competitors, etc. Macro-environment consists of eight main blocks: economic, political and legal, global, environmental, natural, social, cultural, technological, informational, and digital, as well as random factors (Varbanova, 2013, p. 87). It should also be mentioned that pirating also affects the companies as it reduces their revenue.

Figure 12 depicts a possible strategic management model of an independent film production company.

\footnotetext{
${ }^{1}$ Major film studios like Paramount Picture, Warner Bros, etc. based in the USA, belonging to Hollywood studio system.
} 


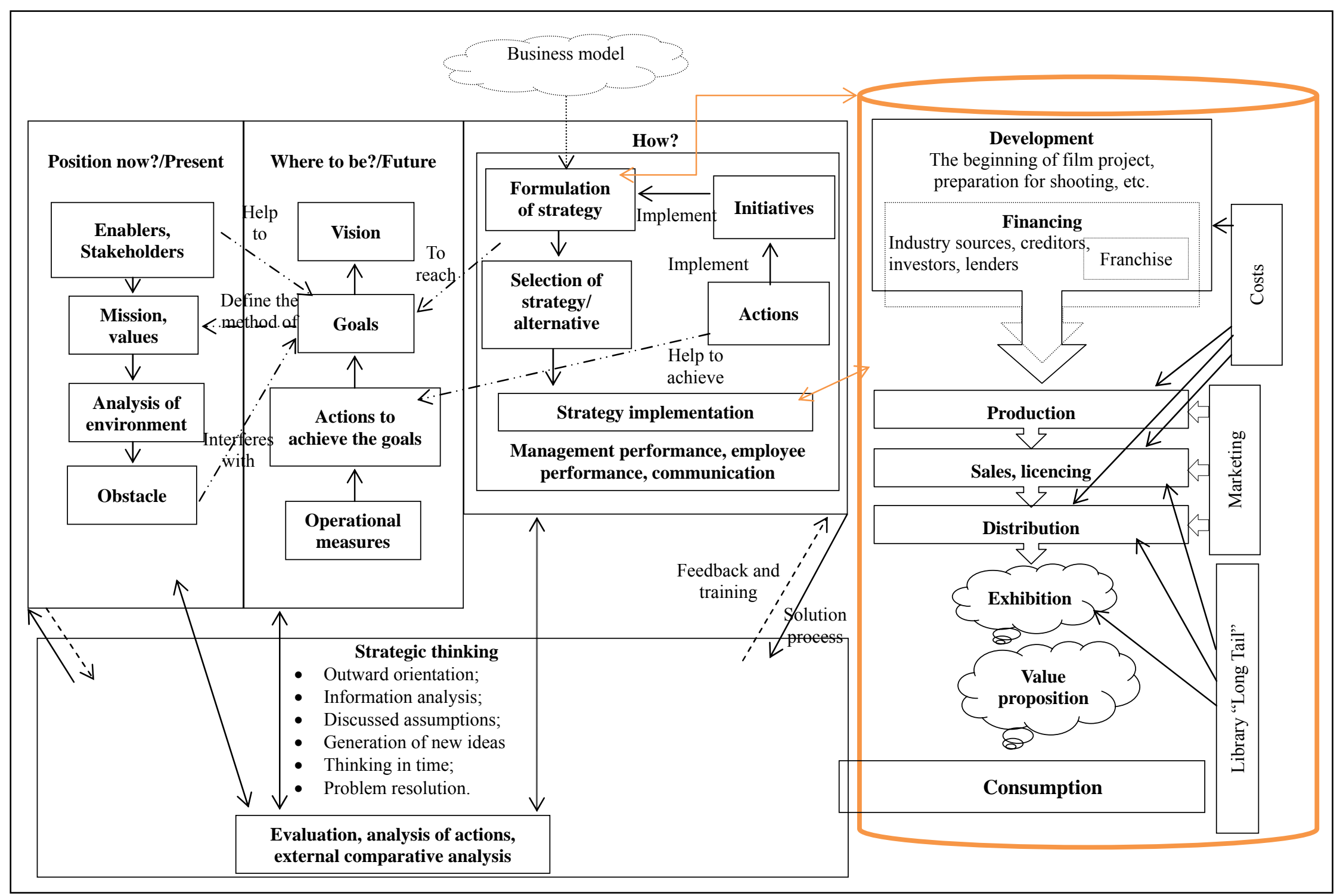

Figure 12. Strategic management model of an independent film production company. Source: Compiled by the author. 
Figure 12 shows that strategic management model includes the value chain of film industry. It signifies that when formulating the strategy, independent film companies cannot only focus on the development and production stages. The company must also plan the distribution, estimate the suitability of other companies for cooperation, and consider a possibility to establish a distribution division as one of its subdivisions as well. Film production companies are also advised to include a marketing plan into their strategy. Marketing can be started in the production process already, when financing is secured and shooting has already started. It is important that the screening/exhibition stage is just implicit, as it is executed by distribution companies, since they are in charge of where the film is going to be screened. The screening itself is executed by various companies that undertake in the screening of films; for example, cinema theatres, television companies, and similar establishments. However, film production companies can execute this stage by employing digital technologies (e.g. to make a film accessible on the Internet). Formulation and implementation of the strategy is executed and based on the stages of development, production, and sales. It is noteworthy that when making films, an important role is played by the financial structure, because the budget for production of feature films can amount to several million euros. Therefore, this model highlights the financing stage. The (aforementioned) sources for film funding can be divided into three main stages:

- industry sources (e.g. income from the pre-sales);

- lenders, creditors (e.g. banks);

- investors (Vogel, 2007).

Franchise is listed as a separate category; however, it is usually the main financing source of major film studies. Let us take Harry Potter franchise for example. It is a cultural phenomenon, the brand name of which has earned Warner Bros and its partners almost 20 billion US dollars. It is a highly viable franchise: films that were based on the books shall be further exploited through theme parks, video games and other means that will continue to generate income to J. K. Rowling, Warner Bros and its partners (Ernst \& Young, 2012, p. 8). However, franchise can be used by independent film production companies and their partners as well.

Not only do film production companies focus on the production of individual films and their realisation, they must also work with the development of the entire company as well. Therefore, each company must first define where it is and what its mission is, and analyse the current situation of the company as well as its microand macro-environment. Then it is possible to define what the company wants for its future: its vision, goals, actions to achieve them and such. According to Nielsen (2009), the aim of an independent Danish film company Zentropa is to become a European mini studio, even though it has more ambitious plans related to its international activities.

If the company knows what it wants to be in the future, it can then start planning how to achieve it, work on its strategy determined by company's business model, development and other important stages. However, not only should a company focus on the production of the film, it must also pay attention to other activities. For example, having invested a part of its revenue to filming equipment, it is possible to reduce production costs and also generate revenue by lending the said equipment.

It can be said that strategic thinking is involved in all stages. It helps make a link between the present and the future prospects. Implementation of strategy also includes good communication with company employees. If employees are misled, or if they receive negative information, they might express resistance to certain changes in the company. 
In conclusion, film development process consists of three main stages: ideation, production, and debriefing. Film budgets must be sustainable. There are three main stages to secure financing: industry sources, lenders/creditors, and investors which are also included when creating a strategic management model for film production company. The main parts of this model are as follows: company's present, future and the vision of how it sees itself in the future. All stages involve strategic thinking, while strategy formulation and implementation feature certain parts of the value chain.

\section{Conclusion}

(1) There are various models of strategic management processes, featuring the following components: strategic thinking, mission, vision, aims, strategic formulation, selection and implementation, strategic analysis, and external comparative analysis. During all stages of the processes, the actions are adjusted and training takes place. In order to implement the strategy successfully, the communication in the company must be elaborate and thorough. When creating its strategy, the company must realise where it is at the moment, what it wants, and how it plans to achieve it.

(2) There are several types of film industry value chains. Independent film project value chain consists of the following stages: development, financing and pre-sales, production, shooting and post-production, international sales and licencing, international distribution, exhibition and exploitation, consumption. Legal advisors, accountants, and consultants work in all stages of the work. Marketing takes a very important place in the chain because it starts in the production stage already.

(3) Film development process consists of three main stages: ideation, production, and debriefing. Film budgets must be sustainable. There are three main stages to secure financing: industry sources, lenders/creditors, and investors. The main parts of strategic management model of independent film companies are as follows: company's present, future and the vision of how it sees itself in the future. All stages involve strategic thinking. When formulating the strategy and looking for ways to implement it, it is important to take into consideration marketing, development and production and other stages of the main product that enable a successful reach of the customer.

\section{References}

Aarhus, F. (2011). Report on business models, value chains and business development services in the audiovisual/creative industries: Cases of the Łódź and Małopolska provinces and West Denmark [pdf]. http://www.firstmotion.eu/art/MediaCenter/FirstMotion/Results\%20and\%20Outcomes/BusinessModelsValueChains_DK_Po land.pdf

Ambler, T. E. (2016). Excellence in strategic management teams. http://www.cssp.com/CD0806a/StrategicManagementTeamExcellence/

Arimavičiūtè, M. (2007). Funkcinių veiklų strateginis valdymas viešojo sektoriaus institucijose. Viešoji politika ir administravimas, 20, 81-89.

Bloore, P. (2009). Re-defining the independent film value chain [pdf]. London: UK Film Council. http://www.bfi.org.uk/sites/bfi.org.uk/files/downloads/redefining-the-independent-film-value-chain.pdf

Campisi, G. (2012). The independent filmmaker's guide to writing a business plan for investors. US: McFarland \& Company.

Daidj, N. (2015). Developing strategic business models and competitive advantage in the digital sector. US: IGI Global.

Domazet, I., Stošic, I., \& Zubovic, J. (2011). Strategic management concept and market restructuring as a response to new challenges of the world financial crisis. Management, 78-87.

Edictive. (2013). The film value chain. http://edictive.com/blog/the-film-value-chain/ 
Ernst \& Young. (2012). Film industry in India: New horizons [pdf]. http://indiainbusiness.nic.in/newdesign/upload/news/New_Horizons_Final.pdf

Failte $\quad$ Ireland. (2013). Understanding strategic management. http://www.failteireland.ie/FailteIreland/media/WebsiteStructure/Documents/2_Develop_Your_Business/1_StartGrow_Your _Business/Understanding-Strategic-Management.pdf

Finney, A. (2008). Learning from sharks: Lessons on managing projects in the independent film industry. Long Range Planning, 41, 107-115.

Finney, A. (2014). Brave new world an analysis of producer/distribution joint ventures. A Report Commissioned by Ffilm Cymru Wales and Creative Skillset [pdf]. http://www.ffilmcymruwales.com/attachments/article/100/Brave\%20New\%20World.pdf

Finney, A., \& Triana, E. (2015). The international film business a market guide beyond Hollywood. London: Routledge.

Fishel, D. (2008). The book of the board effective governance for non-profit organisations (2nd ed.). Australia: The Federation Press.

Frynas, J. G., \& Mellahi, K. (2011). Global strategic management (3rd ed.). UK: Oxford University Press.

Gates, L. P. (2010). Strategic planning with critical success factors and future scenarios: An integrated strategic planning framework [pdf]. Software Engineering Institute.

Goettler, R. L., \& Leslie, P. (2004). Cofinancing to manage risk in the motion picture industry. Journal of Economics \& Management Strategy, 2005.

Guild, W. L., \& Joyce, M. L. (2006). Surviving in the shadow of Hollywood: A study of the Australian film industry. In J. Lampel, J. Shamsie, and T. Lant (Eds.), The business of culture: Strategic perspectives on entertainment and media. UK: Lawrence Erlbaum Associates.

Hill, C. W. L., Jones, G. R., \& Schilling, M. A. (2015). Strategic management: Theory (11th ed.). USA: Cengage Learning.

Hope, T. (2016). The shape of things: Towards a new organizational structure. http://trulyfreefilm.hopeforfilm.com/2010/08/the-shape-of-things-towards-a-new-organizational-structure.html

Jäckel, A. (2003). European film industries. London: British Film Institute.

Kelessidis, V. (2000). Innoregio: Dissemination of innovation management and knowledge techniques [pdf]. Benchmarking. http://www.adi.pt/docs/innoregio_benchmarking-en.pdf

Küng, L. (2008). Strategic management in the media: Theory to practice. London: SAGE Publications LTd.

LCA (Lawyers for the Creatives Arts). (2006). Legal issues in film production [pdf]. https://law-arts.org/pdf/Legal_Issues_in_Film_Production.pdf

Lorenzen, M. (2008). On the globalization of the film industry. Creative Encounters Working Papers. Copenhagen Business School, 1-16

Maurer, R. E. (2008). The strategic management of culturally embedded resources, dissertation. US: ProQuest LLC.

Melnikas, B., \& Smaliukienė, R. (2007). Strateginis valdymas: Mokomoji knyga. Generolo Jono Žemaičio Lietuvos karo akademija.

Mickevičienė, M. (2011). Imonès kompetencijos kaip tvaraus konkurencinio pranašumo kūrimo instrumentas: Strateginis iššūkis. Business System and Economics, 1(1), 8-22.

Morawetz, N. (2007). Finance, policy and industrial dynamics the rise of co-productions in the film Industry [pdf]. Paper to be presented at the DRUID Summer Conference 2007 on Appropriability, Proximity, Routines and Innovation, Copenhagen, http://www2.druid.dk/conferences/viewpaper.php?id=1671\&cf=9

Morden, T. (2007). Principles of strategic management. UK: Ashgate Publishing Limited.

Nielsen, $\quad$ D. $\quad$ K. (2009). Zentropa family. Danish $\quad$ Film $\quad$ Institute. http://www.dfi.dk/Service/English/News-and-publications/FILM-Magazine/Artikler-fra-tidsskriftet-FILM/66/Zentropa-Fami ly.aspx

Nilsen, A. W., \& Smistad, R. (2012). ICT challenges and opportunities for the film industry-A value chain perspective on digital distribution. [pdf]. Project Report. http://archive.northsearegion.eu/files/repository/20140903172212_value-chain-perspective-on-digitaldistribution.pdf

O'Shannassy, T. (2003). Modern strategic management: Balancing strategic thinking and strategic planning for internal and external stakeholders. Singapore Management Review, 25(1), 53-67.

Papulova, E., \& Papulova, Z. (2006). Competitive strategy and competitive advantages of small and midsized manufacturing enterprises in slovakia [pdf]. http://www.g-casa.com/download/Papulova-CompetitiveStrategy.pdf

Peng, M. W. (2014). Global strategy. USA: South-Western Cengage Learning. 
Ritson, N. (2011). Strategic management. Ventus Publishing ApS.

Salas, K., \& Huxley, C. (2014). Enhancing visualisation to communicate and execute strategy. Strategy-to-proccess maps. Journal of Strategy and Management, 7(2), 109-126.

Strazdas, R., Černevičiūtè, J., \& Jančoras, Ž. (2014). Kūrybinio verslo valdymas: Procesu tobulinimas. Mokslo monografija. Kaunas: "Technologija".

Swayne, L. E., Duncan, W. J., \& Ginter, P. M. (2008). Strategic management of health care organizations (6th ed.). England: Jossey-Bass, a Willey Imprint.

Valentinavičius, S. (2009). Verslo strategijos formavimo i̇monejje teoriniai aspektai. Verslas: Teorija ir Praktika. Business: Theory and Practice, Vilniaus Gedimino technikos universitetas, 10(2), 130-141.

Varbanova, L. (2013). Strategic management in the arts. UK: Routledge Taylor \& Francis Group.

Vogel, H. L. (2007). Entertainment industry economics. A guide for financial analysis. Cambridge: Cambridge University Press.

Wirtz, B. W. (2011). Media and internet management. Germany: Gabler Verlag.

Yakowicz, W. (2016). How this little movie company found the formula for big-screen success. http://www.inc.com/will-yakowicz/inc-5000-europe-vertigo-films.html 